\title{
Evaluation of fungicides, biocontrol agents and botanicals for management of damping-off in cabbage seedlings caused by Fursarium moniliforme sheld
}

\author{
Salma Begum*, R. K. Tombisana Devi and N. Iboton Singh \\ Department of Plant Pathology, College of Agriculture, CAU, Imphal- 795004 (Manipur), INDIA \\ *Corresponding author. E-mail: salmabegumsalmabegum@gmail.com \\ Received: December 1, 2014; Revised received: March 3, 2015; Accepted: March 14, 2015
}

\begin{abstract}
The antagonistic effect of 10 fungicides, four biocontrol agents and 10 locally available botanicals in controlling the growth and sporulation of Fusarium moniliforme in vitro were tested. A pot culture experiment was also conducted to study the effect of seed treatment and soil treatment alone or in combination on germination and seedling vigour of cabbage. In vitro evaluation of ten fungicides by poisoned food technique showed that all the fungicides efficiently inhibited complete inhibition of the linear growth of the fungus was observed with Thiophenate methyl, Carbendazim, Mancozeb, Difenconazole, Propiconazole, Hexaconazole, Sixer and Tricyclazole. Sporulation was completely inhibited by all the fungicides evaluated. In dual culture technique of the fungus and biocontrol agents, of the four biocontrol agents evaluated the antagonists, $T$. hamatum completely overgrew the pathogen, $T$. harzianum colonized on half of the growth of the pathogen, $T$. viride remained locked with the fungus at the point of contact and $P$. citrinum formed inhibition zone with the fungus. Sporulation was completely inhibited by all the four antagonists. Among the ten locally available botanicals tested by poisoned food technique in vitro, garlic extract showed maximum fungitoxic property followed wild sage (Lantana camara), onion (Allium cepa), neem (Azadirachta indica), goat weed (Ageratum conyzoides) and marigold (Tagetes erecta) . In pot culture experiment, the least disease incidence was recorded in soil treatment with carbendazim (26\%) followed by T. harzianum (29\%) and $P$. glabrum $(29.7 \%)$. However,considering the various drawbacks and hazardous effects resulting from use of chemicals, biocontrol agents and plant extracts can be recommended to use in raising healthy seedlings free from pre- and post-emergence damping-off.
\end{abstract}

Keywords: Biocontrol agents, Botanicals, Damping-off, Fungicides, Fusarium moniliforme

\section{INTRODUCTION}

Cabbage (Brassica oleracea L. var. capitata) is an economically important and commonly grown vegetable in the world. In India, the major cabbage producing states are Uttar Pradesh, Bihar, Orissa, West Bengal, Assam, Maharashtra and Karnataka. Cabbage. Cabbage suffers from a number of diseases. Among the fungal diseases, damping-off is the most serious disease of cabbage in nursery. It is reported to be caused by different species of Pythium, Rhizoctonia and, Fusarium. (Agrios G N 1997; Laemmlen, 2001). Pythium infection usually begins as a root rot, while Rhizoctonia often infect plants at or near the soil surface (Laemmlen, 2001). Fusarium spp typically cause wilt, attack older seedlings, and are more virulent pathogens in warm soil conditions (Bruehl, 1987) Managing soil borne pathogens that cause damping-off is critical during this period to avoid build-up of inoculums in the soil (Koike et al., 2000). Biocontrol strategy has become the alternative method in recent years due to the indiscriminate and frequent use of chemical agents and its ill-effects to soil and environment (Bohra et al., 2006; Mukhtar, 2007) Therefore, in the present investigation, the efficacy of some promising biocontrol agents, botanical extracts and fungicides were tested for managing damping-off in cabbage and their effect on seedling vigour.

\section{MATERIALS AND METHODS}

Isolation of pathogen: Infected seedlings collected from cabbage seedlings showing typical symptoms of both pre- and post-emergence damping-off were collected and then washed with tap water and rinsed with sterile distilled water. Diseased collar regions were cut into small pieces and then surface sterilized in $0.1 \%$ mercuric chloride for 30 seconds and repeatedly washed with sterilized distilled water to remove traces of mercury and then transferred to water agar media and incubated at $27 \pm 1^{\circ} \mathrm{C}$. Fungal mycelium developed from the infected tissue in water agar media was finally transferred to PDA slants and incubated at $27 \pm 1^{\circ} \mathrm{C}$ to obtain pure culture of Fusarium moniliforme.

In vitro effect of fungicides on the growth and sporulation of the pathogen: The efficacy of ten fungicides namely, carbendazim (Dhanustin 50\% WP) @0.1\%, mancozeb (Dhanuka M-45) @0.2\%, copper oxychloride (Bilcop-50) @ $0.2 \%$, thiophenate methyl (Roko 70 WP) @0.1\%, tricyclazole (Blast-off 75\%WP) @0.1\%, propiconazole (Tilt 25 EC)@0.1\%, difenconazole (Score 25EC) @ $0.1 \%$, hexaconazole (Contaf plus 5\%EC) @0.1\%, Ridomil Mz (metalaxyl 8\% + mancozeb 64\%WP) @ $0.2 \%$ and Sixer (carbendazim 12\% + mancozeb ISSN : 0974-9411 (Print), 2231-5209 (Online) All Rights Reserved (c) Applied and Natural Science Foundation www.ansfoundation.org 
$63 \%$ )@0.2\% were determined on the fungal growth using poisoned food technique in PDA medium (Shervelle, 1979). The per cent inhibition was calculated by following the method described by Vincent (1947) as given below:

$\mathrm{I}=\frac{C-T}{C}$

Where, I $\times 100=$ per cent inhibition; $\mathrm{C}=$ linear growth of the fungus in control $(\mathrm{cm})$ and $\mathrm{T}=$ linear growth of the fungus in treatment $(\mathrm{cm})$

The per cent inhibition on sporulation was calculated after 10 days by following the above formula.

In vitro effect of biocontrol agents on the growth and sporulation of the pathogen: The antagonistic activity of four biocontrol agents namely, Trichoderma harzianum, T. hamatum, T. viride and Penicillium glabrum were tested by using dual culture plate technique as described by Bell et al. (1982) with slight modification. All the ratings were done after contact between the pathogen and the antagonists using modified Bell's scale (Bell et al., 1982).

In vitro effect of botanicals on the growth and sporulation of the pathogen: Ten botanicals, garlic (Allium sativum) at 3\% concentration and ginger (Zingiber officinalis), periwinkle (Vinca rosea), neem (Azadirachta indica), marigold (Tagetes erecta), goat weed (Ageratum conyzoides), Indian pennywort (Centella asiatica), wild sage (Lantana camara), Phlogacanthus (Phlogacanthus thyrsiflorus) and onion (Allium cepa) each at $20 \%$ concentrations were evaluated for their fungitoxic potential against the growth of the fungi. For extraction, plant parts were washed three times in running water, then in sterile water and blotted. The dried plant materials were crushed in 1:1 ratio $(\mathrm{w} / \mathrm{v})$ of sterile distilled water by using mortar and pestle. The extracts thus prepared were filtered through two fold muslin cloth and filtrate was then centrifuged at $1500 \mathrm{rpm}$ for 15 minutes and supernatant was collected and considered as 100 per cent concentration. The efficacy of the botanicals was evaluated by following poisoned food technique (Shervelle, 1979). The per cent inhibition was calculated by following the method as described earlier. Pot culture studies: The pathogens were multiplied in sterilized crushed maize grains for 15 days at $25 \pm$ $1^{\circ} \mathrm{C}$ by shaking every two days to cover the whole grains. Garden soil was collected and sterilized in autoclave for three days consecutively at $15 \mathrm{lb} / \mathrm{inch}^{2}$ for 2 hours. $100 \mathrm{~g}$ of sterilized soil per pot was filled and mixed with $5 \mathrm{~g}$ of each culture separately per pot. Inoculated pots were covered with transparent polythene sheet and kept for 7 days to establish the pathogens in the soil. The biocontrol agents viz., Trichoderma harzianum, T. hamatum, T. viride and Penicillium glabrum were formulated with rice bran. The formulated products used were $10^{8} \mathrm{cfu} / \mathrm{ml}$ concentration.

Effect of soil treatment on seed germination and seedling vigour of cabbage (cv. Pride of India): Carbendazim (@2g/l),garlic (@3\%) and neem (@20\%) and 4 biocontrol agents grown in rice bran (@6g/l)were used to drench the sick soil each@50 ml/ pot. Pots drenched only with water served as control. Each treatment was replicated three times. Untreated 15 seeds were sown in each pot after 2 hours of drenching. Soil moisture was maintained at $80 \%$ by spraying with sterile water. Mortality percentage (pre-emergence damping-off) was recorded after four days of sowing by the following formula:

Pre- emergence damping off $(\%)=$ (Total number of seeds sown that did not germinate due to damping-off / Total number of seeds sown) $\times 100$

Post-emergence damping off (\%) were recorded after 20 days of sowing by the following formula:= (Total number of seedlings - No. of healthy seedlings/ Total number of seedlings) $\times 100$

Twenty days old seedlings were uprooted from each treatment and calculated the seedling vigour by following the formula: $=($ Root length + Shoot length $) \times$ Per cent germination.

The data recorded were analysed statistically wherever necessary. The variations of the different parameters revealed by different treatments were tested for the significance using randomized block design.

\section{RESULTS AND DISCUSSION}

In vitro effect of fungicides on the growth and sporulation of the pathogen: Ten fungicides tested revealed highly fungitoxic effect against the linear growth of the fungus. Carbendazim @0.1\%, mancozeb @ $0.2 \%$, thiophenate methyl @0.1\%, tricyclazole @ $0.1 \%$, propiconazole@0.1\%, difenconazole@0.1\%, hexaconazole@0.1\%, and carbendazim 12\% + mancozeb 63\%@0.2\% could completely inhibit the growth $F$. moniliforme. Whereas $81.11 \%$ and $52.22 \%$ inhibition on the growth of the fungus was observed in metalaxyl $8 \%+$ mancozeb $64 \%$ and copper oxychloride each @ $0.2 \%$ treated plates (Table 1). All the treatments showed significant effect over the control. The fungus could not sporulate in all the fungicides evaluated (Table 1). Similar finding was reported by Nisa et al. (2011) who evaluated four systemic fungicides (carbendazim, myclobutanil, bitertanol, hexaconozole) and three non-systemic fungicides (mancozeb, captan and zineb) for their efficacy on mycelial growth of Fusarium oxysporum by food poisoning technique and found that hexaconozole at concentration of $1000 \mathrm{ppm}$ caused highest reduction of mycelail growth (8.80 $\mathrm{mm})$ followed by carbendazim $(9.40 \mathrm{~mm})$, bitertanol $(18.60 \mathrm{~mm})$ and myclobutanil $(20 \mathrm{~mm})$ at the same concentration. It was also observed from the study that amongst the non-systemic fungicides, mancozeb was found most effective $(14.20 \mathrm{~mm})$ in reducing mycelial growth of thefungi followed by captan $(20.00 \mathrm{~mm})$ and zineb $(22.00 \mathrm{~mm})$.

In vitro effect of biocontrol agents on the growth and sporulation of the pathogen: It was observed that, $T$. harzianum and $T$. viride could come in contact with Fusarium moniliforme after three days of incubation. 
Table 1. Effect of fungicides on the growth and sporulation of $F$. moniliforme in vitro.

\begin{tabular}{|c|c|c|c|c|c|}
\hline Treatments & $\begin{array}{c}\text { Concentration. } \\
(\%)\end{array}$ & $\begin{array}{c}{ }^{* \text { Growth }} \\
\text { (cm) }\end{array}$ & $\begin{array}{c}\text { Inhibition on } \\
\text { Growth (\%) }\end{array}$ & Sporulation & $\begin{array}{c}\text { Inhibition on } \\
\text { Sporulation (\%) }\end{array}$ \\
\hline Carbendazim & 0.1 & $\begin{array}{c}0 \\
(0.71)\end{array}$ & 100 & 0 & 100 \\
\hline Mancozeb & 0.2 & $\begin{array}{c}0 \\
(0.71)\end{array}$ & 100 & 0 & 100 \\
\hline $\begin{array}{l}\text { Copper } \\
\text { oxychloride }\end{array}$ & 0.2 & $\begin{array}{c}4.3 \\
(2.19)\end{array}$ & 52.22 & 0 & 100 \\
\hline $\begin{array}{l}\text { Thiophenate } \\
\text { methyl }\end{array}$ & 0.1 & $\begin{array}{c}0 \\
(0.71)\end{array}$ & 100 & 0 & 100 \\
\hline Tricyclazole & 0.1 & $\begin{array}{c}0 \\
(0.71)\end{array}$ & 100 & 0 & 100 \\
\hline Propiconazole & 0.1 & $\begin{array}{c}0 \\
(0.71)\end{array}$ & 100 & 0 & 100 \\
\hline Difenconazole & 0.1 & $\begin{array}{c}0 \\
(0.71)\end{array}$ & 100 & 0 & 100 \\
\hline Hexaconazole & 0.1 & $\begin{array}{c}0 \\
(0.71)\end{array}$ & 100 & 0 & 100 \\
\hline $\begin{array}{l}\text { Metalaxyl 8\% } \\
\text { +Mancozeb64\% }\end{array}$ & 0.2 & $\begin{array}{c}1.7 \\
(1.48)\end{array}$ & 81.11 & 0 & 100 \\
\hline $\begin{array}{l}\text { Cabendazim12\% } \\
\text { +Mancozeb63\% }\end{array}$ & 0.2 & $\begin{array}{c}0 \\
(0.7)\end{array}$ & 100 & 0 & 100 \\
\hline $\begin{array}{l}\text { Control } \\
\mathrm{CD}_{0.05}\end{array}$ & 0 & $\begin{array}{c}9(3.08) \\
0.04 \\
\end{array}$ & 0 & $8 \times 10^{8}$ & 0 \\
\hline
\end{tabular}

* Mean of three replications; Figures in parentheses are square root transformed values

While T. hamatum came in contact with the fungus after two days of incubation and P. glabrum did not come in contact at all even after ten days of incubation. $T$. hamatum completely overgrew the pathogen (Class I), T. harzianum colonized on half of the growth of the pathogen (Class III), T. viride remained locked with the fungus at the point of contact (Class IV) and $P$. glabrum formed inhibition zone with the fungus (Class VI). Sporulation was completely inhibited by all the four antagonists (Table 2). This finding is supported by the finding of Sundaramoorthy and Balabaskar (2013) who screened various isolates of Trichoderma spp. for their in vitro antagonism against the $F$. oxysporum $\mathrm{f}$. sp. lycopersici by dual cultural technique. The results indicated that ANR-1 inhibited the mycelial growth of $F$. oxysporum f. sp. lycopersici to an extent of 53.00 per cent over control. This was followed by KGI-3 (38.12\%), RTM-5 6 (31.11\%) and KPI-9 (27.22\%).

In vitro effect of botanicals on the growth and sporulation of the pathogen: It is evident from table 3 that among the ten botanicals tested, Garlic extract (a) 3\% showed maximum inhibition $(100 \%)$ on the growth of the fungus, followed by extracts of wild sage $(44.44 \%)$, onion $(33.33 \%)$, neem $(31.11 \%)$, goat weed (31.11\%) and marigold (31.11\%), which were statistically at par. Sporulation was completely inhibited by all the

Table 2. Effect of biocontrol agents on the growth and sporulation of $F$. moniliforme in vitro.

\begin{tabular}{lccc}
\hline Biocontrol agents & Point of contact (days) & Bell's scale & Sporulation \\
\hline Trichoderma harzianum & 3 & Class III & - \\
Trichoderma hamatum & 2 & Class I & - \\
Trichoderma viride & 2 & Class IV & - \\
Penicillium glabrum & No contact & Class VI & - \\
\hline
\end{tabular}

Source: Bell's scale (Bell et al. 1982). 
Table 3. Effect of locally available botanicals on the growth and sporulation of F.moniliforme.

\begin{tabular}{|c|c|c|c|c|c|c|}
\hline Treatments & $\begin{array}{l}\text { Plant } \\
\text { parts } \\
\text { used }\end{array}$ & $\begin{array}{c}\text { Concn. } \\
(\%)\end{array}$ & $\begin{array}{c}* \text { Growth } \\
\text { (cm) }\end{array}$ & $\begin{array}{c}\text { Inhibition } \\
\text { on growth } \\
(\%)\end{array}$ & Sporulation & $\begin{array}{c}\text { Inhibition } \\
\text { on } \\
\text { Sporulation }\end{array}$ \\
\hline Garlic & Clove & 3 & $\begin{array}{c}0 \\
(0.71)\end{array}$ & 100 & 0 & 100 \\
\hline Ginger & Rhizome & 20 & $\begin{array}{c}7.2 \\
(2.77)\end{array}$ & 20 & 0 & 100 \\
\hline Phlogacanthus & Leaf & 20 & $\begin{array}{c}7.8 \\
(2.88)\end{array}$ & 13.33 & 0 & 100 \\
\hline Onion & Bulb & 20 & $\begin{array}{c}6 \\
(2.55)\end{array}$ & 33.33 & 0 & 100 \\
\hline Neem & Leaf & 20 & $\begin{array}{c}6.2 \\
(2.59)\end{array}$ & 31.11 & 0 & 100 \\
\hline Vinca & Leaf & 20 & $\begin{array}{c}8.7 \\
(3.03)\end{array}$ & 3.33 & 0 & 100 \\
\hline $\begin{array}{l}\text { Indian } \\
\text { Pennywort }\end{array}$ & Leaf & 20 & $\begin{array}{c}8 \\
(2.92)\end{array}$ & 11.11 & 0 & 100 \\
\hline Wild sage & Leaf & 20 & $\begin{array}{c}5 \\
(2.35)\end{array}$ & 44.44 & 0 & 100 \\
\hline Marigold & Leaf & 20 & $\begin{array}{c}6.2 \\
(2.59)\end{array}$ & 31.11 & 0 & 100 \\
\hline Goat weed & Leaf & 20 & $\begin{array}{c}6.2 \\
(2.59)\end{array}$ & 31.11 & 0 & 100 \\
\hline Control & - & - & $\begin{array}{c}9 \\
(3.08)\end{array}$ & 0 & $8 \times 10^{8}$ & 0 \\
\hline $\mathrm{CD}_{0.05}$ & & & 0.008 & & & \\
\hline
\end{tabular}

* Mean of three replications; Figures in parentheses are square root transformed values

Table 4. Effect of soil treatment on germination and seedling vigour cabbage (cv. Pride of India) in sick soil $+F$. moniliforme.

\begin{tabular}{|c|c|c|c|c|c|}
\hline Treatments & $\begin{array}{c}\text { Germination } \\
(\%)\end{array}$ & $\begin{array}{c}\text { Pre-emergence } \\
\text { damping-off }(\%)\end{array}$ & $\begin{array}{l}\text { Post-emergence } \\
\text { damping-off }(\%)\end{array}$ & $\begin{array}{c}\text { Total } \\
\text { damping- } \\
\text { off }(\%)\end{array}$ & $\begin{array}{c}\text { Seedling } \\
\text { vigour }\end{array}$ \\
\hline $\begin{array}{l}\mathrm{SS}+(\mathrm{SD}+ \\
\text { carbendazim })\end{array}$ & 83.5 & 16.5 & 9.5 & 26 & 1002 \\
\hline $\begin{array}{l}\mathrm{SS}+(\mathrm{SD}+T . \\
\text { harzianum })\end{array}$ & 80.8 & 19.2 & 9.8 & 29 & 888.8 \\
\hline $\begin{array}{l}\mathrm{SS}+(\mathrm{SD}+T . \\
\text { hamatum })\end{array}$ & 80 & 20 & 10 & 30 & 880 \\
\hline $\begin{array}{l}\mathrm{SS}+(\mathrm{SD}+T . \\
\text { viride) }\end{array}$ & 80.7 & 19.3 & 10.6 & 29.9 & 887.7 \\
\hline $\begin{array}{l}\mathrm{SS}+(\mathrm{SD}+P . \\
\text { glabrum) }\end{array}$ & 82.5 & 17.5 & 12.2 & 29.7 & 907.5 \\
\hline $\begin{array}{l}\mathrm{SS}+(\mathrm{SD}+ \\
\text { garlic) }\end{array}$ & 82.5 & 17.5 & 14.4 & 31.9 & 742.5 \\
\hline $\begin{array}{l}\mathrm{SS}+(\mathrm{SD}+ \\
\text { neem })\end{array}$ & 76.5 & 23.5 & 13.4 & 36.9 & 765 \\
\hline Control & 35.5 & 64.5 & 33 & 97.5 & 177.5 \\
\hline CD 0.05 & 0.211 & & & 0.672 & 1.238 \\
\hline
\end{tabular}

Figures in parentheses are square root transformed values; $* \mathrm{SS}=$ Sick soil; $* \mathrm{SD}=$ Soil drenching 
extracts tested. Bowers and Locke (2000) reported the antifungal activity of Allium sativum against eighteen different fungi including Fusarium spp. Joseph et al., (2008) also reported the bioefficacy of extracts of Azardiachta indica, Artemessia annua, Eucalyptus globulus; Ocimum sanctum and Rheum emodi against Fusarium solani f. sp. Melongenae in vitro.

Effect of soil treatment on seed germination and seedling vigour of cabbage (cv. Pride of India): In sick soil with $F$. moniliforme, maximum germination was observed in soil treatment with carbendazim $(83.5 \%)$ followed by $P$. glabrum $(82.5 \%)$ and garlic $(82.5 \%)$. The least disease incidence was recorded in carbendazim (26.0\%) followed by T. harzianum (29\%) and $P$. glabrum (29.7\%) treated soil. Maximum seedling vigour was recorded in carbendazim (1002) followed by $P$. glabrum (907.5) and T. harzianum (888.8) \%) treated soil (Table 4). The present finding is supported by the findings of Ayub et al. (1998) who evaluated Ridomil (metalaxyl), Captan (captaf) and Dithane M-45 (mancozeb) each at 3 different concentrations applied as soil drench, for their efficacy in controlling tomato seed rot and pre-emergence damping-off and reported that metalaxyl at all concentrations effectively controlled the disease. Captan was effective only at higher concentration. Manoranjitham et al. (2000) reported that soil application of Trichoderma viride and Pseudomonas fluorescens effectively checked the pre-emergence and postemergence damping-off of tomato caused under pot culture experiments.

\section{Conclusion}

In Manipur, $F$. moniliforme was reported to be associated with damping-off of cabbage seedlings. Growth of $F$. moniliforme was completely inhibited by all the fungicides tested except copper oxychloride and metalaxyl 8\% + mancozeb $64 \%$. In dual culture of $F$. moniliforme and biocontrol agents $T$. hamatum completely overgrew the pathogen, T. harzianum colonised on half of the growth, $T$. viride remain locked at the point of contact and $P$. glabrum formed inhibition zone. Of the ten plant extracts tested against $F$. moniliforme, garlic extract showed maximum inhibition followed by extracts of wild sage, neem, goat weed and marigold. Soil treatment with fungicide was comparatively more effective than treatment with biocontrol agents while plant extracts were least effective. However, in view of the hazardous effects of chemicals, effective antagonists and and plant extracts may be recommended to farmers for raising healthy disease free cabbage seedlings.

\section{REFERENCES}

Agrios, G.N (1997). Plant diseasecaused by fungi.. In Fourth edition Plant Pathology. Academic press, USA 268pp.

Ayub, M., Khan, M., Khan, A and Amin, M (1998). Efficacy of some of fungicides for managing pre-emergence damping-off in tomato and their effect on seedlings vigour. Sarhad Journal of Agriculture, 14(5): 475-481.

Bell, D.K., Wells, H.D and Markham, C.R. (1982). In vitro antagonism of Trichoderma spp. against six fungal plant pathogens. Phytopathology, 72: 379-382.

Bohra, B.N., Vyas, B.N. and Mistry, K.B. (2006). Biocontrol agents and neem formulations for management of damping-off in brinjal and chilli. Indian Phytopathology, 59: 223-226.

Bowers, J.H. and Locke, J.C. (2000). Effect of botanical extracts on the population density of Fusarium oxysporum in soil and control of Fusarium wilt in the green house. Plant Disease, 3: 300-305.

Bruehl, G.W. (1987). Soil borne Plant Pathogens.Macmillan Publishing co., New York, NY.

Joseph, B. Dar, M.A. and Kumar, V. (2008). Bioefficacy of Plant Extracts to Control Fusarium solani F. Sp. melongenae Incitant of Brinjal Wilt Global Journal of Biotechnology Biochemistry, 3 (2): 56-59.

Koike, S.T., Gaskell, M., Fouche, C., Smith, R. and Mitchell, J. (2000). Plant disease management for organic crops. University of California Agriculture and Natural Resources Publication No. 7252.

Laemmlen, F. (2000). Damping-off diseases. University of California Davis Agriculture and Natural Resources Publication No. 8041.

Manoranjitham, S.K., Prakasam, V., Rajappan, G. and Amutha, G. (2000). Effect of two antagonists on damping-off disease of tomato. Indian Phytopathology, 53(4): 441-443.

Mukhtar, I. (2007). Comparison of phytochemical and chemical control of Fusarium oxysporum $f$. sp. Ciceri. Mycopathologia, 5:107-110.

Nisa, T., Wani, A.H., Bhat, M. Y., Pala, S.A. and Mir, R. A. (2011). In vitro inhibitory effect of fungicides and botanicals on mycelial growth and spore germination of Fusarium oxysporum Journal of Biopesticides, 4 (1): 53 - 56.

Shervelle, E.G. (1979). Plant disease control. AVI Publishing Company, Inc. West, Post. Connecticut.

Sundaramoorthy, S. and Balabaskar, P. (2013). Biocontrol efficacy of Trichoderma spp. against wilt of tomato caused by Fusarium oxysporum f. sp. Lycopersici. Journal of Applied Biology \& Biotechnology, 1(03): 036-040,

Vincent, J.M. (1947). Distortion of fungal hyphae in presence of certain inhibitors. Nature, 159: 239-241. 